\title{
Chronic Pesticides Exposure and Thyroid Functions among Farmers in Almnaif District - Ismailia Governorate, Egypt
}

\author{
Bassma A. Ibrahim', Shaimaa A. Amer' ${ }^{*}$, Soha E. Younis², Mostafa F. Kofi', and \\ Amani W. Abdel-Halim ${ }^{1}$ \\ ${ }^{1}$ Department of Industrial Medicine and Occupational Health, Faculty of Medicine, Suez Canal University, Egypt \\ and ${ }^{2}$ Departmant of Clinical Pathology, Faculty of Medicine, Suez Canal University, Egypt
}

\begin{abstract}
Background: There is growing evidence that environmental exposure, specifically to pesticides, a potential risk factor for endocrine system malfunction. Aim: The study aims at contributing to improve the wellbeing and productivity of farmers through a better understanding of chronic pesticides exposure and its effect on thyroid functions. Patients and Methods: An analytical crosssectional study was conducted on 43 farmers with active involvement in the preparation, storage and spraying of the pesticides and 43 participants not occupationally exposed to pesticides. All participants were interviewed using a structured questionnaire including sociodemographic characteristics, pesticides exposure characteristics, and safety measures. The blood levels of plasma cholinesterase enzyme, and thyroid hormones (TSH, T4) were measured for all partici-

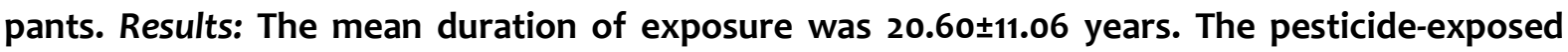
farmers had a statistically significant lower level of plasma cholinesterase enzyme (3969.93 $\pm 1841.84 \mathrm{U} / \mathrm{L})$ compared to the control group (4879.29 $\pm 1950.08 \mathrm{U} / \mathrm{L})(\mathrm{p}<0.05)$. Moreover, thyroid-stimulating hormone level (TSH) was significantly higher in exposed farmers (median $=1.39 \mu \mathrm{lU} / \mathrm{ml})$ compared to controls (median $=0.91 \mu \mathrm{lU} / \mathrm{ml})(p=0.032)$. While the exposed group had a lower level of thyroxine hormone $\left(\mathrm{T}_{4}\right)(6.91 \pm 1.91 \mu \mathrm{g} / \mathrm{dl})$ compared to the control group $(7.79 \pm 2.10 \mu \mathrm{g} / \mathrm{dl})$, with a statistically significant difference between the two groups $(p=0.045)$. Conclusion: Exposure to organophosphates and carbamates affects thyroid function in the form of a decrease in the circulating level of thyroxine hormone, increase in the TSH level.
\end{abstract}

Keywords: Pesticides, Farmers, Thyroid Stimulating Hormone (TSH), thyroxine hormone (T4).

\section{Introduction}

Pesticides are broadly used throughout the world, particularly in agriculture for crop protection $^{(1)}$. Additionally, there has been an increase in the usage of pesticides in developing countries over the past years, which recently account for nearly $20 \%$ of the world's expenditure on pesticides ${ }^{(2)}$. And, despite benefits of using pesticides for pest control, there have been concerns on adverse effects in human health as these compounds are designed to have adverse biological effects on target 
organisms(3). Exposure to pesticides is one of the most serious occupational risks among farmers in developing countries ${ }^{(4-}$ 6). Moreover, shortage of knowledge, careless attitude and awful practices in handling pesticides demonstrate a serious health risk to farmers. On the other hand, the Egyptian environment was injected by 690000 metric tons of pesticides in the last 50 year. Some pesticides have been reported to act as endocrine disruptors with effects on various systems, including the thyroid gland $(7,8)$. Studies focusing on the effect of pesticides on circulating thyroid stimulating hormone (TSH) or thyroid hormone levels, triiodothyronine (T3) and thyroxine ( $\mathrm{T}_{4}$ ), have found conflicting results $(9,10)$. Abou El-magd et al. (2011)(11) in their study to evaluate the effect of pyrethroid exposure on levels of $\mathrm{T}_{3}, \mathrm{~T}_{4}$ and $\mathrm{TSH}$, showed reduced serum levels of both $\mathrm{T}_{3}$ and $\mathrm{T} 4$ and elevated levels of TSH in the exposed group. Furthermore, the results of a Mexican study revealed an increase in TSH serum levels and reduction in $\mathrm{T} 3$ serum levels due to pesticides exposure in floriculture workers $^{(12)}$.

\section{Subjects and Methods}

An analytical cross-sectional study (ex-post facto) was used. The study was carried out on 297 farmers from East Almnaif district in Ismailia governorate. Two groups were studied; exposed to pesticides and non-exposed to pesticides. The sample size was 43 per group which was chosen by systematic random sample. In exposed group farmers handled pesticides at least 2 years and registered in East Almnaif agricultural association owning an agricultural land or their hired pesticides applicators were recruited on the basis of their active involvement in preparation, storage and spraying of the pesticides. Farmers with Chronic liver diseases, any affection of thyroid diabetes, orchitis, varicocele, or recently acquired sexually transmitted diseases were excluded. Also, farmers on lithium carbonate and iodine-containing drugs, amiodarone, dopamine, interferon alpha, glucocorticoids, immunosuppressive dru-gs, sulfonylurea, antipsychotic drugs, antidepressants, spironolactone, thiazides, and betaadrenergic agonists were excluded. For control group, one neighbor per exposed farmer, with same inclusion and exclusion criteria of exposed group except for exposure to pesticides were included in the study.

\section{Data Collection methods:}

\section{A. Structured Interview questionnaire}

A structured interview questionnaire was used to achieve the objectives of the study, including socio-demographic data (age, educational level, marital status, number of children, and smoking status). Pesticides exposure assessment include duration of exposure, the frequency of exposure, the type of pesticides commonly used, type of pesticides handling, methods of mixing and spraying the pesticides. Finally, Safety measures including use of personal protective equipment; personal habits regarding eating, drinking, or smoking during handling of pesticides; hygiene practices after dealing with pesticides.

\section{B. Laboratory Methods}

Under complete aseptic conditions, blood samples (10ml) were collected through venipuncture in coded test tubes, and the specimens were centrifuged to separate the plasma from the cells. After plasma separation, levels of plasma cholinesterase enzyme as a biological indicator of exposure to cholinesterase-inhibiting pesticides was determined by the spectrophotometric method developed by Ellman and expressed as international units per liter. Plasma cholinesterase hydrolyses Butarylthiocholine producing thiocholine and butyrate, and then the reaction between thiocholine and 5, 5'-dithiobis-(2-nitro- 
benzoic) acid (DTNB) gives 2-nitro-5-mercaptobenzoate and yields a yellow compound ${ }^{(13)}$. The increasing color intensity is directly proportional to the cholinesterase activity and can be measured kinetically at wavelengths between 400 and 420 nanometers. The enzyme reference range among male is 3334 and $7031 \mathrm{IU} / \mathrm{L}^{(14)}$.

\section{Assessment of outcome}

1. Thyroid stimulating hormone: Estimation of thyroid stimulating hormone (TSH) in human serum by Enzyme Immunoassay test is based on the principle of a solid phase enzyme-linked immunosorbent assay. The assay system utilizes a unique monoclonal antibody directed against a distinct antigenic determinant on the intact TSH molecule. Serum TSH measurement is the single most reliable test to diagnose all common forms of hypothyroidism and hyperthyroidism. An elevated serum TSH concentration is present in both overt and mild hypothyroidism. Additionally, TSH reference range is $0.270-4.20$ $\mu \mathrm{IU} / \mathrm{mL}^{(15)}$.

2. Total thyroxine: Quantitative determination of total thyroxine (total T4) in human serum by ELISA kit, is based on competitive binding of human thyroxine from serum samples and enzyme-labeled $\mathrm{T} 4$ to $\mathrm{T} 4$-specific antibodies immobilized on microtiter well plates ${ }^{(16)}$. Moreover, T4 reference range is $5.1-14.1 \mu \mathrm{g} / \mathrm{dL}^{(17)}$.

\section{Statistical Analysis}

All statistical analyses were performed using the Statistical Package for Social Science (SPSS) version 20.0. Presentation of the data was done in numerical, tabular and graphical forms as appropriate. Comparison of the outcome and pesticides exposure variables were done by chi-square test for categorical variables, and student's t-test for normally distributed continuous variables of two groups and by ANOVA test for normally distributed continuous variables of more than 2 groups. Non-parametric tests such as Mann-Whitney test and Kruskal Wallis test were used for abnormally distributed continuous variables of two groups, and more than two groups, respectively. Statistical significance was set at $p<0.05^{(18)}$.

\section{Results}

Sociodemographic Characteristics of the Study Participants

The distribution of sociodemographic characteristics among the studied participants is illustrated in table (1). All were males. The mean age of the exposed farmers was $43.56 \pm 13.26$ years, range $21-70$ years, while the mean age of the control group was $37.74 \pm 15.33$ years and range 18-70 years, with no statistically significant difference $(p=0.057)$. With respect to marital status, thirty-seven farmers (86\%) were married compared to twenty-four participants in control group (55.8\%), ( $p=0.002)$. Regarding educational status, fifteen exposed farmers (34.9\%) were illiterate compared to six subjects among control group (14\%) $(p=0.203)$.

Characteristics of Occupational Pesticides Exposure among Exposed Group

The mean duration of exposure was 20.60 \pm 11.06 years with a range of $4-45$ years. Furthermore, pesticides spraying noticed to be a highly seasonal activity with the majority of farmers (86\%) seasonally involved in spraying pesticides, while $14 \%$ of them monthly exposed to pesticides table (2). The pesticides commonly used by the farmers as reported by them is demonstrated in table2. The mostly used compounds were the organophosphate and carbamate insecticides; with the most used active ingredient was malathion, followed by diazinon, dimethoate, methomyl, 
phenthoate used by $95.3 \%-41.9 \%$ of farmers. Furthermore, propineb fungicide, pirimiphosmethyl, Lambda - cyhalothrin , as well as mancozeb and carbosulfan were used by $37.2 \%-16.3 \%$ of farmers, while the frequency of each of others (flusilazole fungicides, cypermethrin, fenarimol, glyphosate) was less than $12 \%$.

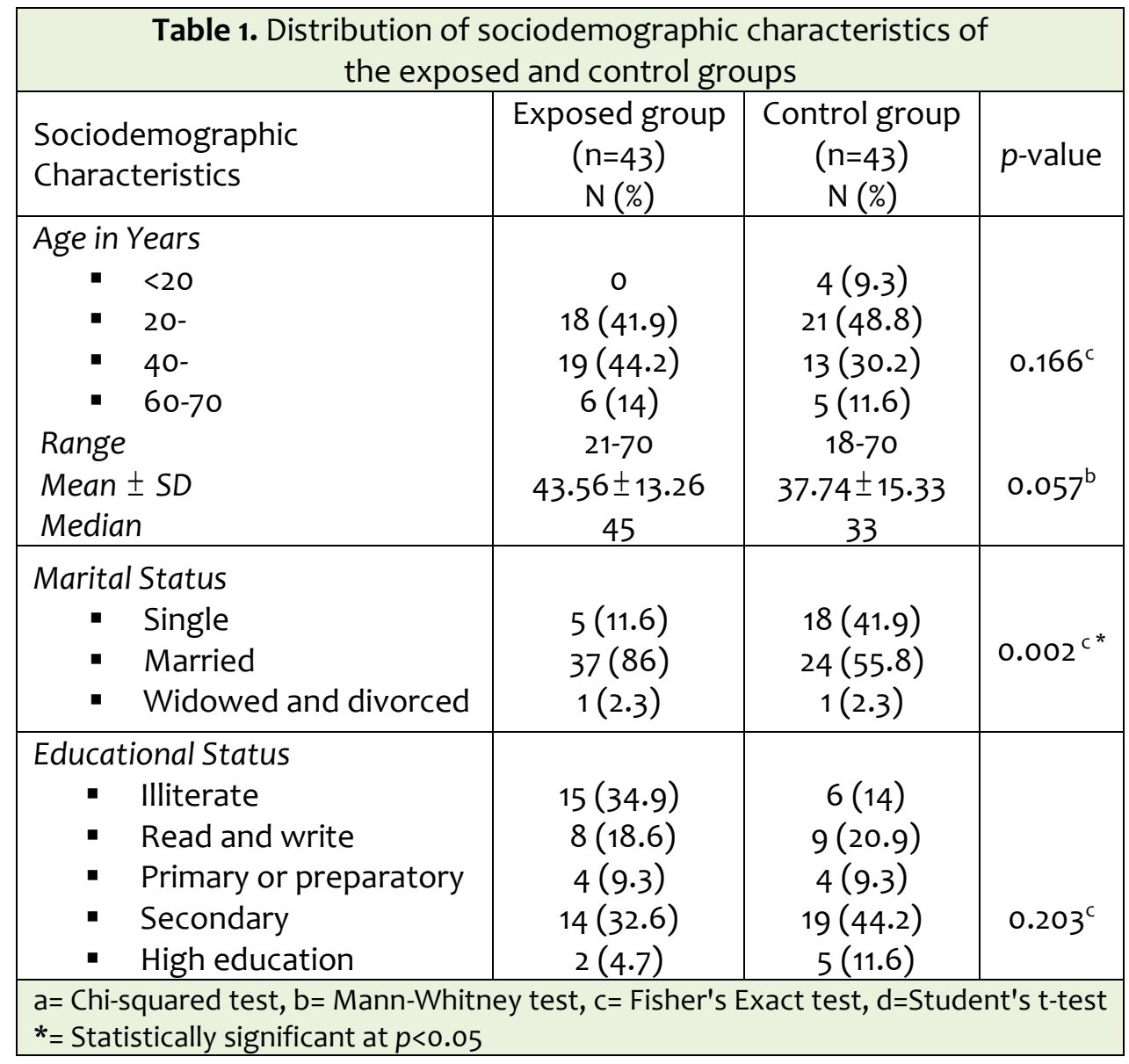

Also, table (2) displays the pesticide handling, application, and among exposed farmers. It showed that thirty-three farmers (77\%) were exposed to pesticides through both mixing and spraying activities and about $23 \%$ of them were exposed to pesticides during only spraying activity. Regarding methods of application, three farmers $(7 \%)$ used only backpack sprayer, and twenty-seven farmers (62.8\%) used only mobile spraying machine (motor), while twenty $(27.9 \%)$ farmers used both methods. Additionally, thirty-nine farmers (90.7\%) accustomed to clean tools used for pesticides mixing and spraying with most of them (97.4\%) performed that practice at field. With respect to the personal protective equipment (PPE) use during pesticide handling, only ten farmers (23.3\%) reported using it. Additionally, the PPE found to be used by the farmers were: i) face mask (20\%), ii) overall and face mask (50\%), iii) gloves, overall, and face mask (30\%) table (3). Moreover, nearly half of farmers (48.8\%) avoid personal habits of eating, drinking, or smoking during handling of pesticides. On the other hand, all of farmers used to engage in hygiene practices after dealing with pesticides, in the form of bathing and changing their clothes at home (Table 3). The levels of plasma cholinesterase enzyme in both exposed and control groups is demonstrated in table 4 . 


\begin{tabular}{|c|c|}
\hline Exposure characteristics & $\begin{array}{l}\text { Exposed farmers }(\mathrm{n}=43) \\
\mathrm{N}(\%)\end{array}$ \\
\hline $\begin{array}{l}\text { Duration of exposure in years } \\
\text { - Range } \\
\text { - Mean } \pm S D\end{array}$ & $\begin{array}{c}4-45 \\
20.60 \pm 11.06\end{array}$ \\
\hline $\begin{array}{l}\text { Frequency of exposure } \\
\text { - Monthly } \\
\text { - Seasonally }\end{array}$ & $\begin{array}{c}6(14) \\
37(86)\end{array}$ \\
\hline $\begin{array}{l}\text { Types of pesticides } \\
\text { Insecticides } \\
\text { Organophosphates } \\
\text { - Malathion } \\
\text { - Diazinon } \\
\text { - } \text { Dimethoate } \\
\text { - Chenthoate } \\
\text { - Pirimiphosmethyl }\end{array}$ & $\begin{array}{l}41(95.3) \\
36(83.7) \\
26(60.5) \\
18(41.9) \\
5(11.6) \\
10(23.3)\end{array}$ \\
\hline $\begin{array}{l}\text { Carbamates } \\
\text { - Methomyl } \\
\text { - Carbosulfan }\end{array}$ & $\begin{array}{l}23(53 \cdot 5) \\
7(16.3)\end{array}$ \\
\hline $\begin{array}{l}\text { Pyrthroids } \\
\text { - Lambda - cyhalothrin } \\
\text { - Cypermethrin }\end{array}$ & $\begin{array}{l}9(20.9) \\
4(9.3)\end{array}$ \\
\hline Fungicides & \\
\hline $\begin{array}{l}\text { Dithiocarbamates } \\
\text { - Propylenebisdithiocarbamate (Propineb) } \\
\text { - Ethylene bisdithiocarbamte (Mancozeb) } \\
\text { - Fenarimol } \\
\text { - Flusilazole }\end{array}$ & $\begin{array}{l}16(37.2) \\
7(16.3) \\
2(4.7) \\
5(11.6)\end{array}$ \\
\hline $\begin{array}{l}\text { Herbicides } \\
\text { - Glyphosate }\end{array}$ & $5(11.6)$ \\
\hline $\begin{array}{c}\text { Mixing pesticides } \\
\text { - No } \\
\text { - Yes }\end{array}$ & $\begin{array}{l}10(23.3) \\
33(76.7)\end{array}$ \\
\hline $\begin{array}{l}\text { Methods of application } \\
\text { - } \text { Backpack sprayer } \\
\text { - } \text { Mobile motorized spraying machine (motor) } \\
\text { - Both backpack sprayer and motor } \\
\text { - By hands and backpack sprayer }\end{array}$ & $\begin{array}{c}3(7) \\
27(62.8) \\
12(27.9) \\
1(2.3)\end{array}$ \\
\hline $\begin{array}{l}\text { Cleaning of mixing and spraying tools } \\
\text { - No } \\
\text { - Yes } \\
\text { Site of cleaning of tools }(n=39) \\
\text { - Field } \\
\text { - Canal }\end{array}$ & $\begin{array}{c}4(9.3) \\
39(90.7) \\
38(97.4) \\
1(2.6)\end{array}$ \\
\hline
\end{tabular}


The mean cholinesterase level among the pesticide-exposed farmers was 3969.93 $1841.84 \mathrm{U} / \mathrm{L}$ compared to $4879.29 \pm$ $1950.08 \mathrm{U} / \mathrm{L}$ control group $(p=0.029)$. As regards the thyroid hormones levels, table (5) demonstrates that thyroid stimulating hormone concentration (TSH) was significantly higher in exposed farmers (median $=1.39 \mu \mathrm{lU} / \mathrm{ml}$ ) compared to controls (median $=0.91 \mu \mathrm{lU} / \mathrm{ml}) \quad(p=0.032)$. While the exposed group had lower level of thyroxine hormone (T4) $(6.91 \pm 1.91$ $\mu \mathrm{g} / \mathrm{dl})$, compared to the control group $(7.79 \pm 2.10 \mu \mathrm{g} / \mathrm{dl})(p=0.045$.

\begin{tabular}{|c|c|c|}
\hline Safety measures & No $(n=43)$ & $\%$ \\
\hline $\begin{array}{l}\text { Use of personal protective equipment } \\
\text { - No } \\
\text { - Yes }\end{array}$ & $\begin{array}{l}33 \\
10 \\
\end{array}$ & $\begin{array}{l}76.7 \\
23.3 \\
\end{array}$ \\
\hline $\begin{array}{l}\text { Type of used protective equipment }(n=10) \\
\text { - Face mask } \\
\text { - Overall and face mask } \\
\text { - Gloves, overall and face mask }\end{array}$ & $\begin{array}{l}2 \\
5 \\
3\end{array}$ & $\begin{array}{l}20 \\
50 \\
30\end{array}$ \\
\hline $\begin{array}{l}\text { Personal habits during pesticides handling*: } \\
\text { - No } \\
\text { - Yes }\end{array}$ & $\begin{array}{l}21 \\
22 \\
\end{array}$ & $\begin{array}{c}48.8 \\
51.2 \\
\end{array}$ \\
\hline $\begin{array}{l}\text { Personal habits after pesticides spraying } \\
\text { - No } \\
\text { - Yes }\end{array}$ & $\begin{array}{c}0 \\
43\end{array}$ & $\begin{array}{c}0 \\
100\end{array}$ \\
\hline
\end{tabular}

\section{Discussion}

The present study found that $62.8 \%$ of exposed farmers had low levels of education, with $34.9 \%$ of them were illiterate, $18.6 \%$ of them could read and write, and $9.3 \%$ of them had primary or preparatory education. Unfortunately, past research reported that illiterate farm workers and those with low levels of education do not seem to understand or care about the instructions indicated on pesticide container labels, often took minimal precautions in either mixing or applying pesticides, and seemed to have lukewarm attitudes toward seeking medical assistance ${ }^{(19,20)}$. The current study results found that insecticides were the most frequently used pesticides, followed by fungicides as reported by farmers. And organophosphates were the pesticide class most used by farmers, followed by carbamates and dithiocarbamate fungicides. Among organophosphates used, malathion, was the most represented followed by diazinon, and dimethoate. And methomyl was the most used carbamates compound. This as mangoes are the main crops cultivated, and like most perennial fruit crops, mango production is plagued with numerous insect pests. The most common ones are fruit flies and Sternochetus mangiferae. Their manifestation in mango fruit requires stringent control measures in form of insecticides for instance organophosphates, carbamates, and pyrethroids to be applied, which ultimately increases cost of production. Additionally, herbicides were used to a lesser extent than other pesticides as the mango tree canopy is not suitable for the growth of weeds, which grow more rapidly where there is strong sunlight ${ }^{(21,22)}$. Most of these 
pesticides belong to WHO Classes II (Moderately hazardous), and III (slightly hazardous) which have been strictly controlled in developed countries(23). Additionally, mobile spraying machine (motor) was the most used method for spraying among these farmers (90.7\%). Moreover, the use of personal protective equipment was inadequate as majority of farmers (76.7\%) did not use any PPE during mixing or spraying pesticides. So, the exposure of farmers can be by dermal route and inhalation since no face masks, respirators, or gloves were used by majority of them. Additionally, half of farmers used to eat and drink water or smoke during pesticides handling thereby ingestion of food contaminated with pesticides can be another route of exposure. Only, the hygienic practices after work in form of washing and changing of clothes were found in all of farmers but were done at home.

Table 4. Plasma cholinesterase enzyme levels among exposed and control groups

\begin{tabular}{|l|c|c|c|}
\hline Laboratory findings & Exposed group $(\mathrm{n}=43)$ & Control group $(\mathrm{n}=43)$ & $\begin{array}{c}p- \\
\text { value }\end{array}$ \\
\hline Plasma cholinesterase activity (U/L) & & & \\
- Mean \pm SD & $3969.93 \pm 1841.84$ & $4879.29 \pm 1950.08$ & $0.029^{\mathrm{d}^{*}}$ \\
- Median & 3765.50 & 4692 & \\
- Range & $973.50-9875$ & $1214-10105$ & \\
\hline \multicolumn{2}{|c|}{$\mathrm{d}=$ Student's t-test; * Statistically significant at $p<0.05$} & \\
\hline
\end{tabular}

So, farmers were not adequately following safe and preventive measures during pesticides handling, increasing the potential of exposure to the used pesticides among them which can result in consequent adverse health effects. The findings of this study about the unsafe behaviors of farmers including lack of PPE use and short reentry intervals are similar to the observations in the literature ${ }^{(24-26)}$ which showed that farmers in developing countries rarely wear protective coverings such as gloves, face masks, goggles, special boots, or wide-brimmed hats during pesticide application. These findings in consistent with that of Ibitayo (2006) (27) $^{(2)}$ who found that, almost all (97\%) the respondents did not wear gloves or eye glasses/goggles or respirators when mixing or applying pesticides. In the present study the mean plasma cholinesterase level of the pesticide exposed farmers was lower than control group. These findings are in agreement with those of Abbassy et al. (2014) ${ }^{(28)}$, who reported that a significant decrease in the activity of serum ChE among pesticide sprayers was more pronounced than among the farm workers and controls. This finding also is in consistent with that of ElSebae (2002) $)^{(29)}$ who found a significant reduction in the level of cholinesterase among workers continuously exposed to organophosphorus and carbamate pesticides. Furthermore, an Indian study, assessed serum cholinesterase (SChE) activity in a group of 50 industrial and 50 agricultural workers exposed to organophosphate compounds. Fifty subjects with no known exposure to organophosphates were enrolled as controls. The mean SChE level was significantly lower in the worker group than the control group. Furthermore, the SChE levels were significantly lower in the industrial worker group versus the agricultural worker group ${ }^{(30)}$. Several non-persistent pesticides as organophosphates (OP), carbamates, dithiocarbamates, and pyrethroids can act as thyroid 
disrupters, affecting the hypothalamic-pituitary-thyroid (HPT) axis at different levels as demonstrated by various experimental studies $(31,32)$. In the current study, thyroid stimulating hormone level (TSH) was significantly higher in exposed farmers compared to controls. While the exposed group had lower level of thyroxine hormone (T4) compared to the control group. These results are in accordance with Previous studie(33-35) who found a decreased in serum levels of both $\mathrm{T}_{3}$ and $\mathrm{T}_{4}$ and increased serum levels of TSH in experimental rats. These finding are also in agreement with that of Arafa et al. (2013)(36) who found that, the pesticides exposed Egyptian farmers had a significantly higher thyroid stimulating hormone (TSH) as well as a significantly lower thyroxine ( $\mathrm{T} 4$ ) serum level when compared to control group. Additionally, finding of this study is in consistence with that of Hassan \& Metwally $(2013)^{(37)}$ who conducted a study to examine the effect of chronic pesticide exposure on thyroid hormones among farmers from El-Shomoot village, Qalubia governorate, Egypt. Their results indicated that the exposed group had significantly lower values of $\mathrm{T} 4$ in comparison to the control group $(p<0.05)$.

\begin{tabular}{|c|c|c|c|}
\hline Thyroid hormones & $\begin{array}{c}\text { Exposed group }(\mathrm{n}=43) \\
\mathrm{N}(\%)\end{array}$ & $\begin{array}{c}\text { Control group }(n=43) \\
N(\%)\end{array}$ & $p$-value \\
\hline $\begin{array}{cl}T S H & (\mu \mathrm{lU} / \mathrm{ml}) \\
\text { - } & \text { Mean } \pm \mathrm{SD} \\
\text { - } & \text { Median } \\
\text { - } & \text { Range }\end{array}$ & $\begin{array}{c}1.454 \pm 0.90 \\
1.39 \\
0.40-5.59\end{array}$ & $\begin{array}{c}1.09 \pm 0.67 \\
0.91 \\
0.263-3.71\end{array}$ & $0.032^{b^{*}}$ \\
\hline $\begin{array}{ll}\mathrm{T} 4(\mu \mathrm{g} / \mathrm{dl}) \\
\text { - } \\
\text { - } \text { Mean } \pm \mathrm{SD} \\
\text { - } \text { Range }\end{array}$ & $\begin{array}{c}6.91 \pm 1.91 \\
7.00 \\
3.50-10.20\end{array}$ & $\begin{array}{c}7.79 \pm 2.10 \\
7.60 \\
2.10-12.20\end{array}$ & $0.045^{\mathrm{d}^{*}}$ \\
\hline
\end{tabular}

Whereas a higher statistically significant levels of TSH among exposed group in comparison to control group was found. The result was also supported by the finding of Farokhi \& Taravati, (2014) ${ }^{(38)}$ who investigated the relation between chronic pesticide exposure and serum levels of thyroid hormones in Iranian pesticide sprayers. They concluded that the TSH level in sprayers was significantly elevated (2.64 $\pm 1.50 \mathrm{mIU} / \mathrm{I})$ compared to control subjects $(1.33 \pm 0.83 \mathrm{mIU} / \mathrm{l})(p=0.007)$. While, an insignificant decrease in T4 levels of sprayers compared to controls were observed.
On the other hand, Manfo et al. (2012)(39) did not find significant changes in $\mathrm{T} 4$ levels during studying of the effect of pesticides on male reproductive function in farmers exposed to pesticides in Djutitsa, west Cameroon. Moreover, a cross-sectional study was conducted to examine the relation between occupational exposure to organophosphate and carbamate pesticides and thyroid hormones of pesticide sprayers of mango plantation in rural Malihabad, India. And its results indicated that most of the pesticide sprayers had normal T4, and TSH levels ${ }^{(40)}$. So, in the present study the 
thyroid gland appears to be somehow, influenced using pesticides. A statistically significant reduction in $\mathrm{T} 4$ levels coupled to a statistically significant increase in TSH levels was observed. It is well known that the levels of TRH, TSH, $\mathrm{T}_{3}$, and $\mathrm{T}_{4}$ are regulated by a negative feedback mechanism at the pituitary gland via inhibition of TRH and TSH synthesis and inhibition of TSH release mainly by decreasing the response of TSH secreting cells to the stimulatory effects of $\mathrm{TRH}^{(41)}$. Consequently, when $\mathrm{T} 4$ level is low, there is an increase in TSH synthesis resulting in increased circulating TSH. These results can be assigned to a mechanism that decreases $\mathrm{T} 4$ level through disturbing the thyroid hormones metabolism. And this may be through pesticides activation of the nuclear receptor constitutive androstane receptor, which in turn induces enzymes involved in thyroid hormone metabolism, including uridine 5'-diphosphateglucuronosyltransferase and sulfotransferase. Subsequently, this may result in increased hepatic metabolism of thyroid hormones, leading finally to decreased plasma T4 and increased TSH level(42). Furthermore, pesticides may also affect the binding of thyroid hormones to thyroid receptors, resulting in an alteration in the expression of genes. This may then influence thyroid hormone metabolism and then alters their levels. In addition, other mechanisms including pesticides inhibition of thyroidal iodine uptake, binding to transport proteins, and altering brain neurotransmitter levels were reported $(43,44)$.

\section{Conclusion}

The present study concluded that the farmers' exposure to pesticides especially organophosphates and carbamates affects thyroid function in form of a decrease in circulating level of thyroxine hormone and an increase in TSH hormone level. Also, farmers are not taking good measures in their pesticide handling practices.

\section{References}

1. Ecobichon D. Pesticide use in developing countries. Toxicology. 2001;160(1-3):27-33.

2. Issa Y, Sham'A FA, Nijem K, Bjertness $E$, Kristensen $P$. Pesticide use and opportunities of exposure among farmers and their families: Crosssectional studies 1998-2006 from Hebron governorate, occupied Palestinian territory. Environ Heal A Glob Access Sci Source [Internet]. 2010;9(1):63. Available from: http://www .ehjournal.net/content /9/1/63

3. Ntzani EE, Ntritsos G, Chondrogiorgi $\mathrm{M}$, Evangelou E, Tzoulaki I. Literature review on epidemiological studies linking exposure to pesticides and health effects. EFSA Support Pub [Internet]. 2013;10 (10): 1-157. Available from: http://doi.wiley. com/10.2903/sp.efsa.2013.EN-497

4. Wesseling C, Aragon A, Castillo L, Corriols M, Chaverri F, de la Cruz E, et al. Hazardous pesticides in Central America. Int J Occup Environ Heal. 2001;7:287-94.

5. Konradsen F, Van der Hoek W, Cole D, Hutchinson G, Daisley $H$, Singh S, et al. Reducing acute poisoning in developing countries options for restricting the availability of pesticides. Toxicology. 2003;192: 249-61.

6. Coronado G, Thompson B, Strong L, Griffith W, Islas I. Agricultural task and exposure to organophosphate pesticides among farmworkers. Environ Heal. 2004;18(112):142-7.

7. Mostafalou S, Abdollahi M. Pesticides and human chronic diseases: Evidences, mechanisms, and perspectives. Toxicol Appl Pharmacol [Internet]. 2013; 268(2): 157-77. Available from: http:// dx.doi.org/10.1016/j.taap.2013.01.025

8. Goldner, , S. W, Sandler DP, Yu F, Shostrom V, Hoppin JA, et al. Hypothyroidism and Pesticide Use 
Among Male Private Pesticide Applicators in the Agricultural Health Study. J Occup Environ Med [Internet]. 2013; 55(10):1171-8. Available from: http://content. wkhealth.com/linkback/openurl?sid= WKPTLP:Iandingpage $\& a n=0004376$ 4-201310000-00007

9. Toft G, Flyvbjerg A, Bonde JP. Environmental Health: A Global Thyroid function in Danish greenhouse workers. Environ Heal A Glob Access Sci Source. 2006;5(32): 1-8.

10. Rádiková Z, Tajtáková $M$, Kocan A, Trnovec T, Šeböková E, Klimeš I, et al. Possible effects of environmental nitrates and toxic organochlorines on human thyroid in highly polluted areas in Slovakia. Thyroid. 2008; 18(3):353-62.

11. Abou El-magd SA, Sabik LME, Shoukry A. Pyrethroid Toxic Effects on some Hormonal Profile and Biochemical Markers among Workers in Pyrethroid Insecticides Company. Life Sci J. 2011;8(1):311-22.

12. Lacasaña $M$, López-flores I, Rodríguez-barranco $\mathrm{M}$, Aguilargarduño C, Blanco-muñoz J, Pérezméndez $O$, et al. Association between organophosphate pesticides exposure and thyroid hormones in $\mathrm{fl}$ oriculture workers. Toxicol Appl Pharmacol [Internet]. 2010;243(1):19-26. Available from: http://dx.doi.org/10.1016/j.taap.2009. 11.008

13. Ellman, G., Courtney, K., FeatherStone, R., \& Andres, V. (1961). A new and rapid colorimetric determination of acetylcholinesterase activity. Biochemical Pharmacology Journal, 7(88-95).

14. Ford, M. (2007). Acute poisoning. In Goldman's Cecil Medicine (23rd ed.). Philadelphia: Saunders Elsevier.

15. Roche Analytics. (2013). Elecsys TSH assay. Retrieved from https:// usdiagnostics.roche. com/en/documentation.html\#/c/AS/n/KIT-

PARAM275MAT11731459122/pb/AND
16. Engall, E. (1980). Estimation of thyroid smoking hormone. In $\mathrm{H}$. Van Vunakis \& J. Langone (Eds.), Methods in Enzymology (pp. 419492). New York: Academic Press.

17. Roche Diagnostics. (2013). Elecsys Testosterone Immunoassay. Retrieved from http://www.rochediagnostics.cz

18. Norman G, Streiner D. PDQ statistics. Hamilton, Ont.: B.C. Decker.; 2003.

19. Salameh PR, Baldi I, Brochard P, Abi Saleh B. Pesticides in Lebanon: A knowledge, attitude, and practice study. Environ Res. 2004;94(1):1-6.

20. Kimani VN, Mwanthi MA. Agrochemicals exposure and health implications in Githunguri location, Kenya. East Afr Med J. 1995;72 (8):531-5.

21. Abdulahi $G$, Obeng-Ofori D, AfrehNuamah K, Billah MK. Perception of mango farmers on the pest status and current management practices for the control of the African invader fly Bactrocera invadens (Diptera: Tephritidae). New York Sci J [Internet]. 2011; 4. Available from: http://www.sciencepub.net/newyor $\mathrm{k}$

22. Clement A-MINA, Anderson RS, Kwame A-NCFB, Osei-Safo D, Boakye AA, Victor A. Pest Management Knowledge and Practices of Mango Farmers in Southeastern Ghana _. J Integr Pest Manag. 2017;8(1):13.

23. World Health Organization. The Who Recommended Classification of Pesticides By Hazard and Guidelines To Classification 2009. World Health Organization. 2010.

24. Clarke EEK, Levy LS, Spurgeon A, Calvert IA. The problems associated with pesticide use by irrigation workers in Ghana. Occup Med (Chic III). 1997;47(5):301-8.

25. Yassin MM. Knowledge, attitude, practice, and toxicity symptoms associated with pesticide use among farm workers in the Gaza Strip. Occup Environ Med [Internet]. 
2002;59(6):387-93. Available from: http://oem.bmj.com/cgi/doi/10.1136/ oem.59.6.387

26. Salameh $P$, Baldi I, Brochard P, Saleh B. Pesticides in Lebanon: a knowledge, attitude, and practice study. Environ Res [Internet]. 2004;94:1-6. Available from: http://www.sciencedirect.com/scien ce/article/pii/So013935103000926

27. Ibitayo OO. Egyptian farmers' attitudes and behaviors regarding agricultural pesticides: Implications for pesticide risk communication. Risk Anal. 2006;26(4):989-95.

28. Abbassy MA, Marei AE, Mohamed A, Mossa AH. Adverse biochemical effects of various pesticides on sprayers of cotton fields in El-Behira Governorate,Egypt. Biomed Aging Pathol [Internet]. 2014; 4(3): 251-6. Available from: http://dx.doi. org/10.1016/j.biomag.2014.04.004

29. El-Sebae A. Blood group, serum and saliva enzymes as biomarkers for pes- ticide exposure. Alexandria J Agric Res. 2002;47(3):185-95.

30. Singh B, Dogra T, Tripathi C. A Study of Serum Cholinesterase Activity in Agricultural and Industrial Workers Occupationally Exposed to Organophosphate Insecticides. Internet J Med Toxicol. 2002;5(2):9.

31. Crofton KM. Thyroid disrupting chemicals mechanisms and mixtures. Int J Androl. 2008;31(2):209-223.

32. Diamanti-Kandarakis E, Bourguignon JP, Giudice LC, Hauser R, Prins GS, Soto $A M$, et al. Endocrine-disrupting chemicals: An Endocrine Society scientific statement. Endocr Rev. 2009;30(4):293-342.

33. El-Bakhmy AS, Abdel-Aziz MZ, EMAM EE. Protective role of selenium and vitamin $E$ against the detrimental effect of some pesticides on fertility and some hormones of cross breed bulls at Sharkia Governorate. Benha Vet Med J. 2011;(Special Issue(11)):88-94.

34. Wang C, Chen F, Zhang Q, Fang Z.
Chronic toxicity and cytotoxicity of synthetic pyrethroid insecticide cisbifenthrin. J Environ Sci. 2009;21(12):1710-5.

35. Finch J, Osimitz T, Gabriel K, Martin T, Henderson W, Capen C, et al. A mode of action for induction of thyroid gland tumors by Pyrethrins in the rat. Toxicol Appl Pharmacol. 2006; 214(3):253-62.

36. Arafa A, Afify M, Samy N. Evaluation of Adverse Health Effects of Pesticides Exposure [Biochemical \& Hormonal] among Egyptian Farmers. J Appl Sci Res. 2013;9(7):4404-9.

37. Hassan OM, Metwally ES. Reproductive And Thyroid Hormones Among Male Agricultural Workers Exposed To Pesticides. Egypt J Community Med. 2013;31(4): 1-16.

38. Farokhi F, Taravati A. Pesticide exposure and thyroid function in adult male sprayers. Int J Med Investig [Internet]. 2014;3(4):127-32. Available from: http://www. intjmi.com

39. Manfo F, Moundipa PF, D??chaud H, Tchana AN, Nantia EA, Zabot MT, et al. Effect of agropesticides use on male reproductive function: A study on farmers in Djutitsa (Cameroon). Environ Toxicol. 2012;27(7):423-32.

40. Jamal F, Haque QS, Singh S. The influence of organophosphate and carbamate on sperm chromatin and reproductive hormones among pesticide sprayers. Toxicol Ind Health. 2016;32(8):1527-36.

41. Chiamolera MI, Wondisford FE. Minireview: thyrotropin-releasing hormone and the thyroid hormona feedback mechanism. Endocrinology. 2009;150(3):1091-1096.

42. Boas $M$, Feldt-Rasmussen $U$, Skakkebaek NE, Main KM. Environmental chemicals and thyroid function. Eur J Endocrinol. 2006;154(5):599-611.

43. Zoeller RT. Environmental Chemicals Impacting the Thyroid: Targets and 
Consequences. Thyroid [Internet]. 2007;17(9):811-7. Available from: http://www.liebertonline.com/ doi/abs/10.1089/thy.2007.0107

44. Rakitsky VN, Koblyakov VA, Turusov VS. Nongenotoxic (epigenetic) carcinogens: Pesticides as an example. A critical review. Teratog Carcinog Mutagen. 2000;20(4):22940. 